\title{
Enzyme Polymorphism and Genetic Population Structure in Escherichia coli and Shigella
}

\author{
By HOWARD OCHMAN, THOMAS S. WHITTAM, \\ DOMINIQUE A. CAUGANT $†$ AND ROBERT K. SELANDER* \\ Department of Biology, University of Rochester, Rochester, New York 14627, U.S.A.
}

(Received 1 February 1983; revised 20 April 1983)

\begin{abstract}
Electrophoretically demonstrable variation in 12 enzymes was studied in more than 1600 isolates of Escherichia coli from human and animal sources and in 123 strains of the four species of Shigella. All 12 enzymes were polymorphic; and the number of allozymes (mobility variants), which were equated with alleles, averaged 9.3 per locus in E. coli. For Shigella species, the mean number of alleles was 2.9 per locus. Some $77 \%$ of the allozymes recorded in Shigella were shared with $E$. coli. A total of 302 unique genotypic combinations of alleles over the 12 loci (electrophoretic types, ETs) was distinguished, of which 279 represented $E$. coli and 23 were Shigella. Among electrophoretic types, mean allelic diversity per locus was 0.52 for $E$. coli and 0.29 for Shigella. It was estimated that there are, on the average, about 0.3 detectable codon differences per locus between pairs of strains of $E$. coli and Shigella, which is roughly equivalent to 1.2 amino acid differences per enzyme. Evidence that the enzyme loci studied are a random sample of the genome is provided by a significant positive correlation between estimates of genetic divergence between pairs of strains obtained by DNA reassociation tests and estimates of genetic distance between the same strains based on electrophoresis.

A principal components analysis of allozyme profiles revealed that the $302 \mathrm{ET}$ s fall into three overlapping clusters, reflecting strong non-random associations of alleles, largely at four loci. Each of the four ETs of $E$. coli that have been most frequently recovered from natural populations has an allozyme profile that is very similar to, or identical with, the hypothetical modal ET of one of the groups. ETs of Shigella fall into two of the groups. No biological significance can at present be attributed to the genetic structure revealed by multilocus electrophoretic techniques. The electrophoretic data are fully compatible with other molecular and more conventional evidence of a close affinity between $E$. coli and Shigella, and they raise questions regarding the present assignments of certain strains to species. In support of evidence from DNA reassociation tests and serotyping, the present study suggests that $S$. sonnei is homogeneous in chromosomal genotype.
\end{abstract}

\section{INTRODUCTION}

Numerous techniques have been employed to detect genetically determined variation in Escherichia coli and related forms of bacteria in an effort to establish criteria for classifying and identifying strains in genetic, epidemiological, and ecological research. Serotyping has revealed more than 1000 distinct combinations of antigens of the $\mathrm{O}, \mathrm{K}$, and $\mathrm{H}$ groups in isolates of $E$. coli (Eveland et al., 1971; Ørskov et al., 1976, 1977; Bettelheim, 1978); and analysis of chromosomal DNA has shown that pairs of strains may differ by as much as $4 \%$ in $\mathrm{G}+\mathrm{C}$ content, $23 \%$ in genome size, and $25 \%$ in nucleotide sequence, as indexed by reassociation experiments (Brenner

$\dagger$ Present address: Department of Clinical Immunology, Institute of Medical Microbiology, University of Göteborg, Göteborg, Sweden.

Abbreviation: ET, electrophoretic type. 
et al., 1969, 1972a, b; Brenner \& Falkow, 1971; Brenner, 1981). Variation in nucleotide sequence also has been measured by comparing restriction endonuclease fragments (Anilionis \& Riley, 1980; Harshman \& Riley, 1980) and by sequencing certain regions of the genome (Hori \& Osawa, 1979; Milkman \& Crawford, 1983). Other methods of detecting genetic diversity include metabolic typing (biotyping) (Krieg \& Lockhart, 1966; Colwell et al., 1974; Johnson et al., 1975; Sakazaki et al., 1976; Crichton \& Old, 1979, 1982); bacteriocin typing (Gillies, 1978); phage typing (Milch, 1978); testing sensitivity to various chemicals ('resistotyping') (Elek et al., 1973; Old et al., 1980, 1981); electrophoretic analysis of proteins of pili (Jann et al., 1981), of the outer membrane (Achtman et al., 1983), and of whole cells (Bowman et al., 1967; Baptist et al., 1969, 1975; Goullet, 1973, 1980); and the characterization of plasmids (Jamieson et al., 1979; Williams \& Warner, 1980; Sansonetti et al., 1981, 1982; review in Elwell \& Shipley, 1980).

Although these methods have revealed extensive variation in $E$. coli and related forms, they have not provided data suitable for answering questions concerning even the most basic aspects of population genetics (Jacquard, 1974; Lewontin, 1974). Among these are the following: (1) What proportion of the genetic loci is polymorphic in a population or species? (2) What are the numbers and frequencies of alleles at the average locus in the genome, and what is the variance of genic (allelic) diversity among loci? (3) How do allele frequencies vary temporally within populations and geographically among populations? (4) To what extent can the genotypic arrays of strains in populations (i.e. the combinations of alleles over loci) be predicted from the allele frequencies at individual loci?

To address these questions, protein gel electrophoresis may be used to measure allelic variation at many loci by screening randomly selected sets of enzymes for allozymes - genetically controlled variants of enzymes differing in net electrostatic charge as a consequence of one or more amino acid substitutions. Although this multilocus approach has long been part of the standard methodology of research on the population genetics of higher organisms (e.g. Lewontin \& Hubby, 1966; Lewontin, 1974; Nei, 1975; Ayala, 1976; Harris et al., 1977; Selander \& Whittam, 1983), it has not been widely applied to bacteria. Its major strength is that it permits one to estimate allelic variation at individual loci (and an average over all loci studied) and yields measures of genetic distance, which can be interpreted in terms of numbers of nucleotide and amino acid substitutions between different individuals, populations, and taxonomic groups (Nei, 1975).

In application to bacterial populations, the multilocus electrophoretic approach has several advantages over other methods of measuring genetic variation. For example, a particular advantage over serotyping and bacteriocin typing is the fact that genotypic data can be obtained for all isolates - none is untypable. Because most of the enzyme loci thus far examined in $E$. coli are represented in populations by many alleles (Selander \& Levin, 1980), the power of the technique to resolve genetic differences between strains is very high; and the chances of similarity between strains over a large number of loci due to convergent evolution are very low.

In this paper, we describe the results of a study of the population genetics and evolutionary relationships of $E$. coli and Shigella, in which we have examined electrophoretically demonstrable polymorphism in enzymes encoded by 12 gene loci in isolates derived from many natural sources.

\section{METHODS}

Sources of strains. The collection of 1608 isolates of $E$. coli analysed in this study is largely a compilation of material from previous electrophoretic studies of enzyme polymorphism conducted in our laboratory (Selander \& Levin, 1980; Caugant et al., 1981, 1983). The collection includes: (1) 550 isolates obtained from a single human host in Massachusetts over a period of 11 months; (2) 17 from 16 infants in a hospital nursery in Massachusetts; (3) 34 from 30 adults and children in Iowa; (4) 55 from 41 individual mammals of 28 species in a zoo and in natural habitats in North America; (5) 1 from a lizard; (6) 2 from well water; (7) 1 each of laboratory strains $E$. coli $\mathrm{B}$ and C; (8) 24 of E. coli K12, representing 5 major lineages (Bachmann, 1972); (9) 121 from urine specimens of 121 Swedish women with urinary tract infections; (10) 47 from urine specimens of 47 schoolgirls in Sweden having asymptomatic bacteriuria; and (11) 100 from 100 Swedish schoolgirls not having urinary tract infections. We have also included data from an unpublished survey of variation in (12) 457 isolates from 3 families in Massachusetts, 
each comprising 2 adults, 2 children, and 2 pets (cats, dogs); and (13) 198 isolates from 2 families in New York state.

Except as noted, isolates were obtained from faecal samples. Methods of isolating and identifying $E$. coli are described by Selander \& Levin (1980) and by Caugant et al. (1981).

Additionally, we have examined 123 strains of 4 species of Shigella from various parts of the world. Shigella boydii: 22 strains from 20 patients in various hospitals in Massachusetts and 2 strains from Yugoslavia. Shigella dysenteriae: 9 strains from Massachusetts and 1 from Nepal. Shigella sonnei: 20 strains derived from a local episode of dysentery in the Holyoke/Chicopee area of Massachusetts (traced to contamination of a swimming pool), and 18 strains from Spain, Portugal, Yugoslavia, Tunisia, India, Hong Kong, and several Greek islands. Shigella flexneri: 21 strains from associated hosts involved in an episode of dysentery following a picnic in the Worcester/Shrewsbury area of Massachusetts, and 13 strains of world-wide origin. The strains of Shigella were collected between 1976 and 1981. Those from Massachusetts were supplied, through Dr Bruce R. Levin, by Mr Rex Bacchieri, Microbiology Department, Massachusetts State Laboratory, Jamaica Plains, Massachusetts; and those from other areas were furnished by Dr Knut Lincoln, of Göteborg, Sweden.

To compare results obtained by electrophoresis of enzymes with those provided by DNA reassociation tests, we examined 11 strains of $E$. coli and 4 strains of Shigella that were earlier analysed by Brenner et al. (1972a). The strains of $E$. coli were K12, C600, B (Albany), BB, W3442K, 01 A, 02A, 04, and A-D 01 111-69 and 05 3121-63, representing the Alkalescens-Dispar biotype. The strains of Shigella were dysenteriae 2, boydii 1, flexneri 2124570 , and sonnei (virulent).

Electrophoresis of enzymes. Techniques of horizontal starch-gel electrophoresis and the selective demonstration of specific enzyme activity used in our laboratory are those described by Selander et al. (1971), with minor modifications for application to bacteria (Caugant et al., 1981). The 12 enzymes that are common to all the abovecited surveys of enzyme polymorphism are listed in Table 1 . In the case of the 15 strains obtained from Brenner, variation in indophenol oxidase, phosphoglucomutase, and glyceraldehyde-3-phosphate dehydrogenase was also studied. The structural genes corresponding to most of the enzymes assayed have been mapped to chromosomal locations (Bachmann \& Low, 1980).

Using standard procedures of protein electrophoresis, we directly compared the relative mobilities of alternative forms of each enzyme occurring in strains. These allozymes (electromorphs) were equated with alleles at the individual loci encoding the enzymes and were numbered in order of increasing anodal mobility on gels. In strains lacking activity of a particular enzyme, we scored the alleles as 'null'. In this manner, the combination of alleles at each of the 12 enzyme loci (or 15 in the case of Brenner's strains) was determined for each strain. Following Caugant et al. (1981), each distinctive combination of alleles (genotype) was designated as an electrophoretic type (ET) (see examples in Table 3).

\section{RESULTS}

Proportion of loci polymorphic and number of alleles. All 12 enzymes were polymorphic in E. coli, and the number of alleles ranged from 3 for glucose-6-phosphate dehydrogenase to 23 for $\beta$ galactosidase, with a mean of $9 \cdot 3$ per locus (Table 1). In Shigella, the mean number of alleles was only 2.9 per locus (range, 1-6), and two of the loci were monomorphic. Some $77 \%$ of the allozymes recorded in Shigella are electrophoretically indistinguishable from those occurring in E. coli.

Number of electrophoretic types. Among the 1731 isolates studied, we identified 302 unique combinations of alleles or ETs, of which 279 represent $E$. coli and 23 represent Shigella. The mean numbers of isolates per ET were 5.5 for E. coli and 5.6 for Shigella.

Distribution of ETs in hosts. There is a striking difference between E. coli and Shigella in the frequency distribution of number of different hosts from which individual ETs were isolated (Table 2). (An ET isolated two or more times from the same individual host was counted only once.) For $E$. coli, $76 \%$ of the ETs were each recovered from only one host; and only $12 \%$ were isolated from three or more hosts. [The converse is certainly not the case: the intestinal floras of individual hosts include numerous ETs; Caugant et al. (1981) detected 53 ETs in one host over an 11-month period.] In contrast, the ETs of Shigella on the average were recovered from many more hosts ( 5.8 hosts per ET) than were those of E. coli $(1.7$ hosts per ET). This difference reflects in part the infection of closely associated hosts by a single clone in local episodes of dysentery. But this is not the whole explanation, for the 13 strains of Shigella sonnei from worldwide sources and the 21 strains from associated hosts in Massachusetts all represent a single ET. 
Table 1. Genetic diversity $(H)$ at 12 enzyme loci in natural populations of $E$. coli and Shigella $H=1-\sum x_{i}^{2}$, where $x_{i}$ is the frequency of the $i^{\text {th }}$ allele. The number of alleles is indicated in parentheses.

\begin{tabular}{|c|c|c|c|c|c|}
\hline Enzyme & Symbol & $\begin{array}{c}\mathrm{EC} \\
\text { number }\end{array}$ & $\begin{array}{c}E . \text { coli } \\
n=279\end{array}$ & $\begin{array}{l}\text { Shigella } \\
n=23\end{array}$ & $\begin{array}{c}\text { Combined } \\
n=302\end{array}$ \\
\hline Alcohol dehydrogenase & ADH & 1.1 .1 .1 & $0.729(7)^{*}$ & $0.163(3)^{*}$ & $0.682(8)^{*}$ \\
\hline Malate dehydrogenase & $\mathrm{MDH}$ & 1.1 .1 .37 & 0.221 (7) & $0.227(2)$ & $0.223(8)$ \\
\hline Isocitrate dehydrogenase & IDH & 1.1 .1 .41 & $0.440(6)^{*}$ & $0.526(3)$ & $0 \cdot 450(7)^{*}$ \\
\hline $\begin{array}{l}\text { 6-Phosphogluconate } \\
\text { dehydrogenase } \\
\text { Glucose-6-phosphate }\end{array}$ & 6PG & 1.1 .1 .44 & $0.715(20)^{*}$ & $0.627(6)^{*}$ & $0.739(20)^{*}$ \\
\hline $\begin{array}{l}\text { Glucose-6-phosphate } \\
\text { dehydrogenase } \\
\text { Glutamic-oxaloacetic }\end{array}$ & G6P & 1.1 .1 .49 & $0.192(3)$ & $0(1)$ & $0.178(3)$ \\
\hline transaminase & GOT & 2.6 .1 .1 & $0.049(4)$ & $0 \cdot 420(4)$ & 0.084 \\
\hline Adenylate kinase & AK & 2.7 .4 .3 & $0.423(5)$ & $0(1)$ & 0.399 \\
\hline$\beta$-Galactosidase & $\beta \mathrm{GA}$ & 3.2 .1 .23 & $0.893(23)^{*}$ & $0.083(2)^{*}$ & $0.904(23)^{*}$ \\
\hline $\begin{array}{l}\text { Phenylalanyl-leucine } \\
\text { peptidase }\end{array}$ & PE2 & $3.4 .11 .-$ & $0.598(9)^{*}$ & $0.083(2)$ & $0.569(9)^{*}$ \\
\hline Aconitase & $\mathrm{ACO}$ & 4.2 .1 .3 & $0.616(9)$ & $0.556(4)^{*}$ & $0.648(10)^{*}$ \\
\hline Phosphoglucose isomerase & PGI & 5.3 .1 .9 & $0.594(10)$ & $0 \cdot 159(2)$ & $0.596(11)$ \\
\hline $\begin{array}{l}\text { Mannose phosphate } \\
\text { isomerase }\end{array}$ & MPI & 5.3 .1 .8 & $0.710(9)^{*}$ & $0.646(5)$ & $0.729(11)^{*}$ \\
\hline
\end{tabular}

Table 2. Frequency distribution of ETs isolated from different numbers of unassociated hosts Each entry is the number of distinct ETs found in the specified number of hosts.

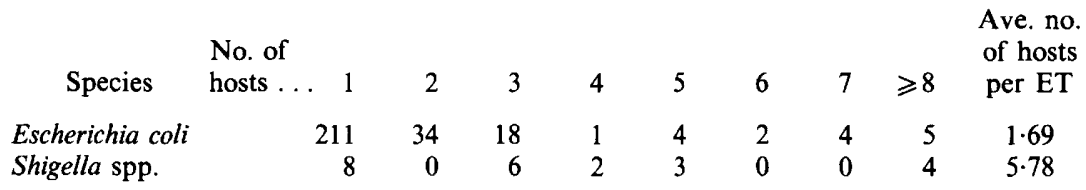

Some ETs of $S$. boydii isolated in 1976 in Massachusetts are electrophoretically identical to those recovered following an episode of dysentery in 1981. We do not have extensive information on the temporal stability of $E$. coli genotypes, because most ETs in our collection were obtained from single hosts. However, isolates that are electrophoretically indistinguishable from laboratory strain $\mathrm{K} 12$, which was originally obtained from a human host over 50 years ago (Bachmann, 1972), have been repeatedly found in natural populations in the course of our studies and, in fact, represent the fourth most commonly recorded ET of $E$. coli. Moreover, those ETs of $E$. coli that are most frequently recovered are not restricted geographically or in type of host. For example, ET-136 is represented by isolates from human siblings and a dog in Massachusetts and from 11 girls with urinary tract infections and 2 healthy girls in Sweden.

Genetic diversity among electrophoretic types. Estimates of genetic diversity (Nei, 1975), calculated from the frequencies of alleles in the $302 \mathrm{ETs}$, are presented in Table 1. The mean diversity per locus over all ETs of $E$. coli is 0.52 , which is similar to the value of 0.47 reported by Selander \& Levin (1980) for 20 enzyme loci assayed in 109 strains from natural populations of humans and a variety of mammals. There is much less genetic diversity in the ETs of Shigella, the comparable value being only $0 \cdot 29$.

Genetic distance between $E$. coli and Shigella. We have calculated two measures of genetic distance between $E$. coli and Shigella (Fig. 1). One measure expresses distance as the mean number of loci at which alternative alleles occur (i.e. the number of mismatches) in pairwise comparisons between all ETs in the two taxa. The other measure of distance is Nei's (1975) $D$, 


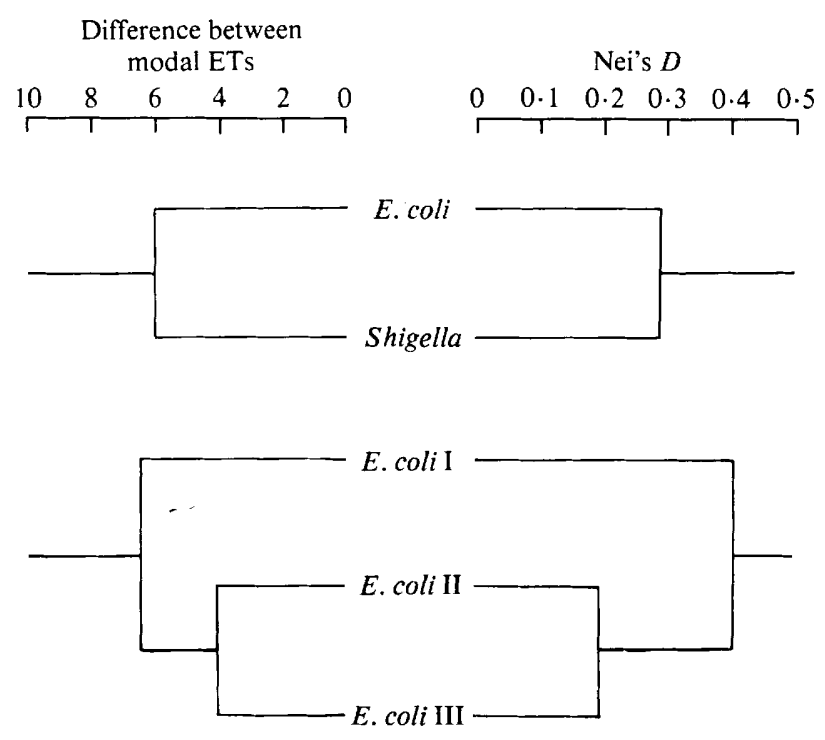

Fig. 1. Two measures of genetic distance between $E$. coli and Shigella species and among the three groups of $E$. coli. Left-hand side: the number of loci at which alternative alleles occur in hypothetical modal ETs of $E$. coli and Shigella. Right-hand side: Nei's genetic distance $(D)$, calculated from allele frequencies within each taxon or group.

which, with certain assumptions, can be interpreted in terms of mean net amino acid differences per polypeptide or codon differences per locus between strains. Our analysis yields a mean estimate of about 0.3 detectable codon differences per locus between pairs of strains of $E$. coli and Shigella. On the assumption that electrophoresis detects about $25 \%$ of all amino acid substitutions (which probably is a conservative estimate: Bonhomme \& Selander, 1978; Ramshaw et al., 1979; Ayala, 1982), this result translates to about 1.2 amino acid differences for the average enzyme.

Genetic structure of populations. To visualize patterns of genetic structure, as reflected by similarity of allozyme profiles among ETs, we used principal components analysis (Sneath \& Sokal, 1973). In preparation for this analysis, we converted the electrophoretic data into a binary code by considering each allele as a variable that can occur in one of two states, either present (1) or absent (0), in a strain; and the total number of variables is simply the sum of the alleles over all loci. This method of coding is sensitive to single allelic substitutions between strains and can accommodate null phenotypes.

The results of the analysis are shown in Fig. 2, which is a plot of the scores for all ETs on the first two principal axes (factors). These axes explain about $10 \%$ of the total variance among ETs, which suggests that there are strong correlations in the occurrence of particular allozyme combinations in ETs.

The projection of ETs on the first two axes reveals that they fall into three overlapping clusters. From each of the three clusters, we chose a random set of 20 ETs and, by means of a discriminate function analysis, classified each of the remaining ETs into one of these three groups (see Fig. 2). For the discriminate analysis, the electrophoretic data were coded by translating the consecutive numbers representing allozyme mobilities of an enzyme on to a common scale by ranging (Sneath \& Sokal, 1973). By standardizing the allelic variation at each locus into the range 0 to 1 , this method weights all loci equally, even though the number of allozymes varies over loci. It also retains information about the relative mobility of different allozymes; but because null alleles could not be coded, they were classified with the most common allozyme allele at a locus. 


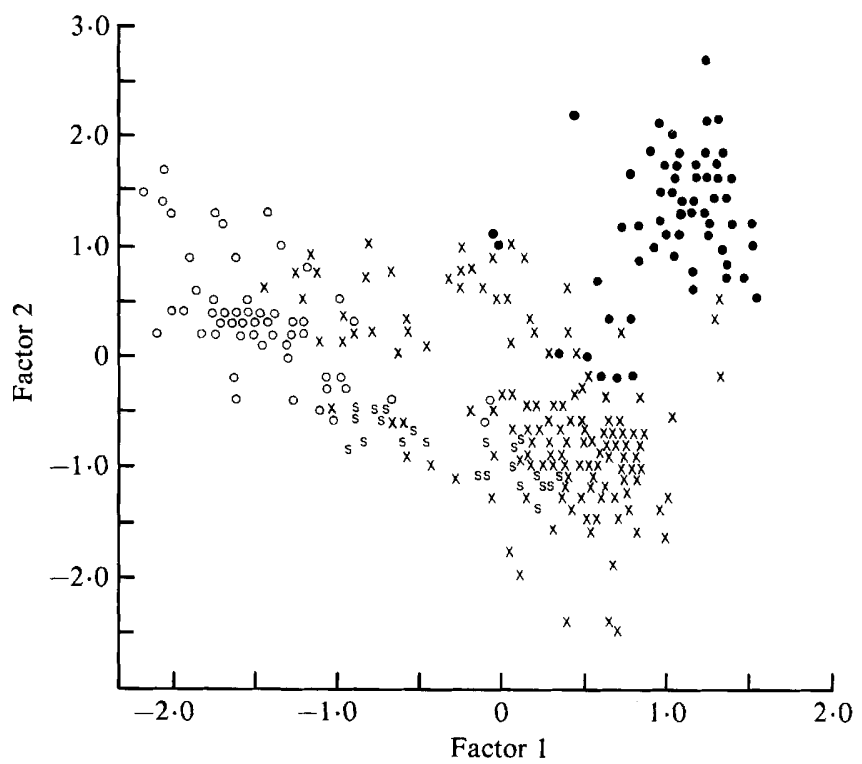

Fig. 2. Plot of scores of electrophoretic types (ETs) of E. coli $(n=279)$ and Shigella $(n=23)$ for the first two principal factors. Electrophoretic types of Groups I, II, and III of $E$. coli are designated by $O, \times$, and, respectively. S indicates Shigella. (From Whittam et al., 1983, with permission of the authors.)

Table 3. Comparison of modal and most common ETs in three groups of E. coli

Entries are allozyme designations for the three modal ETs and the four most frequently recovered ETs. The number of unassociated host individuals from which each ET was recovered is indicated in parentheses. The allozyme designations that differ in the modal and the most common ETs of a group are shown in bold type.

$\begin{array}{lcccccccc}\text { Enzyme } & \overbrace{\begin{array}{c}\text { Modal } \\ \text { ET }\end{array}} & \begin{array}{c}\text { ET-4 } \\ (12)\end{array} & & \overbrace{\begin{array}{c}\text { Modal } \\ \text { ET }\end{array}}^{\text {I }} & \begin{array}{c}\text { ET-99 } \\ (17)\end{array} & \overbrace{\begin{array}{c}\text { Modal } \\ \text { ET }\end{array}}^{\text {II }} \begin{array}{c}\text { ET-136 } \\ (16)\end{array} & \begin{array}{c}\text { ET-58 } \\ (28)\end{array} \\ \text { ADH } & 1 & 1 & 6 & 6 & 6 & 6 & 6 \\ \text { MDH } & 2 & 2 & \mathbf{2} & \mathbf{6} & 2 & 2 & 2 \\ \text { IDH } & 2 & 2 & 5 & 5 & 5 & 5 & 5 \\ \text { 6PG } & 6 & 6 & \mathbf{6} & \mathbf{4} & 6 & 6 & 6 \\ \text { G6P } & 2 & 2 & 2 & 2 & 2 & 2 & 2 \\ \text { GOT } & 3 & 3 & 3 & 3 & 3 & 3 & 3 \\ \text { AK } & 4 & 4 & \mathbf{4} & \mathbf{5} & \mathbf{5} & \mathbf{4} & 5 \\ \beta \text { BGA } & 15 & 15 & \mathbf{1 5} & 7 & 7 & 7 & 7 \\ \text { PE2 } & 5 & 5 & 5 & 5 & \mathbf{4} & 4 & \mathbf{2} \\ \text { ACO } & 7 & 7 & \mathbf{6} & \mathbf{7} & 6 & 6 & 6 \\ \text { PGI } & 4 & 4 & 7 & 7 & 7 & 7 & 7 \\ \text { MPI } & 3 & 3 & 7 & 7 & 3 & 3 & 3\end{array}$

Within $E$. coli, the average genetic distance between strains in Group I and those in Groups II and III $(D=0 \cdot 41)$ is about $30 \%$ greater than that between $E$. coli as a whole and Shigella $(D=$ $0 \cdot 30$ ) (Fig. 1). Groups II and III, however, are more closely related, with a genetic distance of about $0 \cdot 20$ detectable codon differences per locus.

For each of the three groups, we constructed the hypothetical modal ET, which is the combination of the most common allele at each of the 12 enzyme loci within a particular subdivision. (Note that because the genotypes of the modal types were calculated from the allele frequencies of the ETs in the clusters, rather than from the total numbers of isolates, they are not influenced by the frequencies of isolation of the various ETs.) The four ETs of E. coli that have 


\begin{tabular}{lllllll}
60 & \multicolumn{9}{c}{$\mathrm{D}(\%)$} \\
\hline & 50 & 40 & 30 & 20 & 10 & 0
\end{tabular}

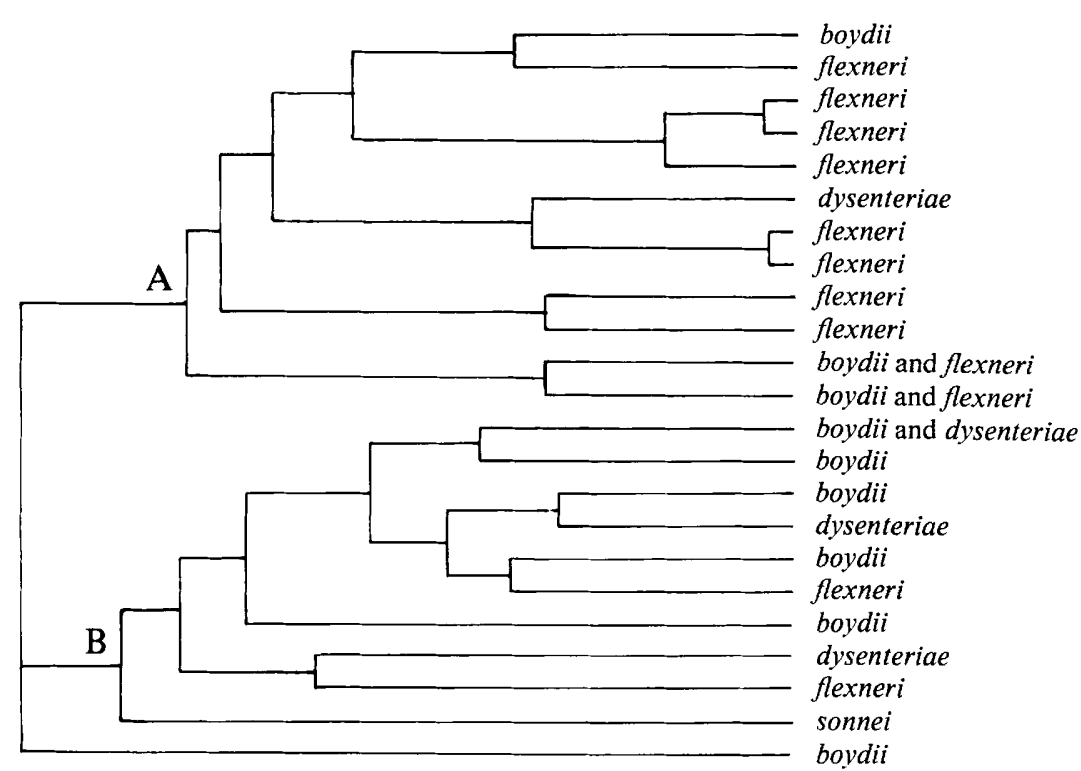

Fig. 3. Dendrogram of the 23 electrophoretic types of Shigella, produced by average linkage clustering. [D, which is equal to one minus Jaccard's similarity coefficient (Sneath \& Sokal, 1973), is given as the percentage of the maximum value.]

been most frequently recovered (isolated from 10 or more hosts) are distributed in all three groups, and each has an allozyme profile that is very similar, or in one case identical, to the modal ET of a cluster (Table 3). The modal ETs differ at 5, 4, and 7 loci for the comparisons of $E$. coli Groups I and II, E. Coli Groups II and III, and E. coli Groups I and III, respectively. It is noteworthy that the genotypic combination of the commonest alleles in the sample of all $302 \mathrm{ETs}$ has never been recovered.

Variation within Shigella. A dendrogram of the 23 ETs of Shigella in our sample, produced by average linkage clustering (Sneath \& Sokal, 1973), reveals two major clusters (Fig. 3). Cluster A consists largely of ETs of flexneri but also includes ETs representing certain strains of boydii and dysenteriae. Cluster B contains ETs of all four species; and sonnei appears to be the most distantly related form. ET-2, which is represented by two isolates of boydii of the same serotype from an individual in Massachusetts, is quite distinct, joining clusters A and B at the $40 \%$ level of similarity.

\section{DISCUSSION}

An assumption underlying many of the applications of the multilocus electrophoretic technique to population genetics and systematics is that the loci encoding the enzymes analysed are a representative sample of the genome (Lewontin \& Hubby, 1966; Lewontin, 1974). If this is indeed the case, one would expect to find a positive correlation between estimates of relatedness among a group of strains obtained by enzyme electrophoresis and those derived from DNA hybridization, which measures similarity in total nucleotide sequence. Such a relationship has been demonstrated in higher organisms (Wilson et al., 1977) and is also apparent in the case of $E$. coli and Shigella (Table 4). For strains that earlier were analysed by DNA hybridization by Brenner et al. (1972a, 1973), Table 4 shows separately estimates of genetic divergence from $E$. coli strains K12 and BB as standards. For both comparisons, there are significant positive 
Table 4. Relationships between estimates of genetic divergence obtained by electrophoresis of 15 enzymes and by DNA reassociation experiments

\begin{tabular}{|c|c|c|c|c|}
\hline \multirow[b]{2}{*}{ Strain } & \multicolumn{2}{|c|}{$\begin{array}{l}\text { Compared with } \\
\text { E. coli } \mathrm{K} 12\end{array}$} & \multicolumn{2}{|c|}{$\begin{array}{c}\text { Compared with } \\
E \text {. coli } \mathrm{BB}\end{array}$} \\
\hline & $\begin{array}{c}\text { No. of } \\
\text { allozyme } \\
\text { differences }\end{array}$ & $\begin{array}{l}\Delta T_{m} \text { at } \\
75^{\circ} \mathrm{C}^{*}\end{array}$ & $\begin{array}{l}\text { No. of } \\
\text { allozyme } \\
\text { differences }\end{array}$ & $\begin{array}{l}\Delta T_{m} \text { at } \\
75^{\circ} \mathrm{C}^{*}\end{array}$ \\
\hline E. coli $\mathrm{K} 12$ & $0 \dagger$ & - & 3 & $0 \cdot 2$ \\
\hline $\mathrm{C} 600$ & 2 & $0 \cdot 3$ & 4 & 0.5 \\
\hline B & 5 & 1.0 & 6 & NM \\
\hline BB & 3 & $0 \cdot 6$ & $0+$ & - \\
\hline B (Albany) & 5 & $0 \cdot 4$ & 6 & 0.6 \\
\hline N3442K & 4 & $1 \cdot 0$ & 1 & 0.4 \\
\hline $01 \mathrm{~A}$ & 9 & $2 \cdot 8$ & 9 & $2 \cdot 7$ \\
\hline $02 \mathrm{~A}$ & 12 & $1 \cdot 7$ & 13 & $1 \cdot 7$ \\
\hline 04 & 12 & $2 \cdot 0$ & 13 & 1.7 \\
\hline A-D01 & 6 & $1 \cdot 2$ & 7 & 1.7 \\
\hline A-D05 & 3 & $1 \cdot 3$ & 5 & 0.9 \\
\hline Shigella boydii 1 & 3 & NM & 3 & NM \\
\hline S. flexneri & 6 & $0 \cdot 8$ & 7 & $1 \cdot 0$ \\
\hline S. sonnei (virulent) & 4 & 0.7 & 3 & NM \\
\hline S. dysenteriae 2 & 7 & $0 \cdot 5$ & 8 & $1 \cdot 2$ \\
\hline Correlation $(r)$ & $\begin{array}{c}0.6 \\
(P< \\
n=\end{array}$ & $05)$ & $\begin{array}{r}0.7 \\
(P< \\
n=\end{array}$ & $01)$ \\
\hline
\end{tabular}

NM, Not measured.

${ }^{*} \Delta T_{m}$ values from Brenner et al. $(1972 a) . \quad+$ Standard.

correlations between the percentage divergence in nucleotide sequences estimated by the decrease in thermal elution midpoint $\left(\Delta T_{m}\right)$ at $75^{\circ} \mathrm{C}$ and the number of allozyme differences at enzyme loci.

Our analysis of electrophoretically demonstrable polymorphism in 12 enzymes has revealed extensive genetic structure in natural populations of $E$. coli. Because high rates of recombination between loci in the absence of natural selection for specific combinations of alleles (epistatic selection) would tend to prevent the generation and maintenance of genetic structure, it is important to note that, contrary to the suggestion by Milkman $(1973,1975)$, available evidence indicates that recombination occurs very infrequently in natural populations (Selander \& Levin, 1980; Caugant et al., 1981; Achtman et al., 1983). With low rates of recombination, natural populations are mixtures of more or less independently evolving lines (clones); and we would expect non-random associations of alleles at different loci, even in the absence of epistatic selection (Kubitscheck, 1974; Koch, 1974, 1981; Maynard Smith \& Haigh, 1974; Thomson, 1977; Ohta, 1982). Elsewhere, we (Whittam et al., 1983) have tested deviations from independent assortment of alleles over loci in $E$. coli by comparing the distribution of the number of allozyme differences between ETs in all pairwise comparisons to an hypothetical one based on allele frequencies in all ETs (Brown et al., 1980). The variances of the observed and expected distributions differed significantly, indicating a strong degree of multilocus association (i.e. linkage disequilibrium) among loci. We have also shown that significant allele associations at four loci are largely responsible for the clustering of ETs into three groups.

We cannot at present attribute any biological significance to the subspecific genetic structure in $E$. coli revealed by our analysis or account for maintenance of the three clusters of genotypes in the face of mutation and recombination, even at very low rates. In an attempt to obtain clues to possible biological correlates of polymorphic enzyme variation, we cross-referenced each ET of $E$. coli with certain attributes of its source population, and, when sample sizes were sufficient for comparison, performed association tests. With respect to host type (human vs. non-human), diet of host (carnivorous vs. herbivorous), and association with urinary tract infections (ETs isolated 
from urine of women with such infections vs. ETs from faeces of healthy persons), we have found no significant group-character associations. However, there is a geographic component to the distribution of ETs, as shown by the fact that among 30 human hosts in Massachusetts, including individuals in three families and a group of newborn infants, ETs in Groups I and II are disproportionately represented. An analysis of within- and between-region components of the total variance in linkage disequilibrium in $E$. coli will be presented elsewhere.

The results of our multilocus electrophoretic study are compatible with those of other recent work on variation at the molecular level, which have confirmed earlier suggestions, based on metabolic typing, serotyping, and other more conventional characters (Edwards \& Ewing, 1972; Johnson et al., 1975; Rowe et al., 1976; Sanderson, 1976), of a close affinity between Shigella and $E$. coli. The molecular evidence comes from a large variety of sources, including studies of DNA reassociation (Brenner \& Falkow, 1971; Brenner et al., 1972a); nucleotide sequences of the ompA (Braun \& Cole, 1982) and trp regions (Nichols et al., 1980); complementarity in tRNAs and 5S rRNAs (Brenner et al., 1977); copy number of the IS1 insertion element (Nyman et al., 1981); sequence of ribosomal proteins (Hori \& Osawa, 1978); the N-terminal amino acid sequence of the tryptophan synthetase $\alpha$ subunit (Li \& Hoch, 1974); immunoelectrophoresis of $\beta$-lactamase (Bergstrom et al., 1982); and electrophoresis of enzymes (Bowman et al., 1967; Baptist et al., 1969; Goullet, 1980). Although most of these studies compared relatively small numbers of strains and therefore did not adequately determine the extent of genetic variation within species in relation to that between species, the cumulative evidence demonstrates that Shigella and $E$. coli are sufficiently similar to warrant them being placed in the same genus. Justification for the continued use of conventional nomenclature for these bacteria is based entirely on historical and clinical considerations (Brenner et al., 1973; Ørskov et al., 1977).

The dendrogram of ETs in Fig. 3 only loosely corresponds to the current classification of Shigella into four species. Particularly significant is the observation that, in several cases, the same ET is represented by isolates received as boydii and flexneri or as boydii and dysenteriae. The classification of certain strains of Shigella has been questioned (Johnson et al., 1975; Petrovskaya \& Bondarenko, 1977; Petrovskaya \& Khomenko, 1979), and the electrophoretic evidence presented here and elsewhere (Goullet, 1980) clearly indicates the need for taxonomic revision. Multivariate analyses of as many as 200 phenotypic characters have produced a variety of schemes of taxonomic relationship among the four species, but, in general, dysenteriae, boydii, and flexneri show greater overall similarity to one another than to sonnei (Colwell et al., 1974; Johnson et al., 1975; Dodd \& Jones, 1982). As shown in Fig. 3, our analysis demonstrates a similar pattern of relationships.

The fact that the studies of Brenner et al. (1973) on DNA reassociation detected marked divergence between the boydii 13 strain and all other strains of Shigella suggests that boydii is genetically more heterogeneous than the other species; and our results support this hypothesis. Note particularly that one strain of boydii is markedly different from all other strains of Shigella that we studied.

The evidence from DNA reassociation tests (Brenner et al., 1973), serotyping (Ørskov et al., 1977), and our study of allozyme variation suggests that all strains of Shigella sonnei are genetically homogeneous, insofar as the chromosomal genotype is concerned. A relatively limited amount of variation in metabolic characters (Szturm-Rubinsten, 1964), sensitivity to certain toxic chemicals (Helgason \& Old, 1981; Old et al., 1981), and some other phenotypic characters (Dodd \& Jones, 1982) has been detected, together with some minor variation in esterase zymograms associated with biotype (Goullet, 1980), but the extent to which these variations represent in vitro mutation (see discussion in Helgason \& Old, 1981) or are mediated by plasmids is unknown. It has recently been shown that resistance to several antibiotics, bacteriocin production, and expression of the form I somatic antigen, all of which characters have been used in epidemiological studies, are controlled by factors carried by plasmids (Jamieson et al., 1979; Kopecko et al., 1980; Sansonetti et al., 1981).

The research was supported by grants from the National Science Foundation (DEB 78-23263) and the National Institutes of Health (GM 22126). 


\section{REFERENCES}

Achtman, M., Mercer, A., Kusecek, B., Pohl, A., Heuzenroeder, H., Aaronson, W., Sutton, A. \& SILVER, R. P. (1983). Six widespread bacterial clones among Escherichia coli $\mathrm{K} 1$ isolates. Infection and Immunity 39, 315-335.

Anilionis, A. \& Riley, M. (1980). Conservation and variation of nucleotide sequences within bacterial genomes: Escherichia coli strains. Journal of Bacteriology 143, 355-365.

Ayala, F. J. (Editor) (1976). Molecular Evolution. Sunderland, Massachusetts: Sinauer Associates.

AYALA, F. J. (1982). Genetic variation in natural populations: problems of electrophoretically cryptic alleles. Proceedings of the National Academy of Sciences of the United States of America 79, 550-554.

BachmanN, B. J. (1972). Pedigrees of some mutant strains of Escherichia coli K-12. Bacteriological Reviews 36, 525-557.

BaCHMANN, B. J. \& Low, K. B. (1980). Linkage map of Escherichia coli K-12, Edition 6. Microbiological Reviews 44, 1-56.

Baptist, J. N., Shaw, C. R. \& Mandel, M. (1969). Zone electrophoresis of enzymes in bacterial taxonomy. Journal of Bacteriology 99, 180-188.

Baptist, J. N., Thomas, D., BUtLeR, M. A. \& Matney, T.S. (1975). Genetic studies of bacterial isozymes. In Isozymes, IV. Genetics and Evolution, pp. 371-379. Edited by C. L. Markert. New York: Academic Press.

Bergstrom, S., Olsson, O. \& Normark, S. (1982). Common evolutionary origin of chromosomal betalactamase genes in enterobacteria. Journal of Bacteriology 150, 528-534.

Bettelheim, K. A. (1978). The source of 'OH' serotypes of Escherichia coli. Journal of Hygiene $\mathbf{8 0}$, 83-113.

Bonhomme, F. \& Selander, R. K. (1978). The extent of allelic diversity underlying electrophoretic protein variation in the house mouse. In Origins of Inbred Mice, pp. 569-589. Edited by H. C. Morse, III. New York: Academic Press.

Bowman, J. E., Brubaker, R. R., Frischer, H. \& CARSON, P. E. (1967). Characterization of enterobacteria by starch-gel electrophoresis of glucose-6phosphate dehydrogenase and phosphogluconate dehydrogenase. Journal of Bacteriology 94, 544-551.

Braun, G. \& Cole, S. T. (1982). The nucleotide sequence for major outer membrane protein OmpA of Shigella dysenteriae. Nucleic Acids Research 10, 2367-2378.

BRENNER, D. J. (1981). Introduction to the family Enterobacteriaceae. In The Prokaryotes, Vol. II, pp. 1105-1127. Edited by M. P. Starr, H. Stolp, H. G. Truper, A. Balows \& H. G. Schlegel. Berlin: Springer-Verlag.

BRENNER, D. J. \& FAlkow, S. (1971). Molecular relationships among members of the Enterobacteriaceae. Advances in Genetics 16, 81-118.

Brenner, D. J., Fanning, G. R., Johnson, K. E., Citarella, R. V. \& Falkow, S. (1969). Polynucleotide sequence relationships among members of Enterobacteriaceae. Journal of Bacteriology 98, 637650.

Brenner, D. J., Fanning, G. R., Skerman, F. J. \& FALKOW, S. (1972a). Polynucleotide sequence diver- gence among strains of Escherichia coli and closely related organisms. Journal of Bacteriology 109, 953965.

Brenner, D. J., Fanning, G. R., Steigerwalt, A. G., Ørskov, I. \& ØRsKov, F. (1972b). Polynucleotide sequence relatedness among three groups of pathogenic Escherichia coli strains. Infection and Immunity 6, 308-315.

Brenner, D. J., Fanning, G. R., Miklos, G. V. \& Steigerwalt, A. G. (1973). Polynucleotide sequence relatedness among Shigella species. International Journal of Systematic Bacteriology 23, 1-7.

Brenner, D. J., Fanning, G. R., Steigerwalt, A. G., SodD, M. A. \& Doctor, B. P. (1977). Conservation of transfer ribonucleic acid and $5 S$ ribonucleic acid cistrons in Enterobacteriaceae. Journal of Bacterio$\log y$ 129, 1435-1439.

Brown, A. H. D., Feldman, M. W. \& Nevo, E. (1980). Multilocus structure of natural populations of $\mathrm{Hor}$ deum spontaneum. Genetics 96, 523-536.

Caugant, D. A., Levin, B. R. \& Selander, R. K. (1981). Genetic diversity and temporal variation in the $E$. coli population of a human host. Genetics 98 , 467-490.

Caugant, D. A., Levin, B. R., Lidin-Janson, G., Whittam, T. S., Svanborg EdÉN, C. \& Selander, R. K. (1983). Genetic diversity and relationships among strains of $E$. coli in the intestine and those causing urinary tract infections. In Host Parasite Relationships in Gram-negative Infections (Progress in Allergy, vol. 33), pp. 203-227. Edited by L. A. Hanson, P. Kallos \& O. Westphal. Basel: Karger. Colwell, R. R., Johnson, R., WAN, L., Lovelace, T. E. \& BRENNER, D. J. (1974). Numerical taxonomy and deoxyribonucleic acid reassociation in the taxonomy of some gram-negative fermentive bacteria. International Journal of Systematic Bacteriology 24, 422-433.

CRIChton, P. B. \& OLD, D. C. (1979). Biotyping of Escherichia coli. Journal of Medical Microbiology 12, 473-486.

Crichton, P. B. \& OLd, D. C. (1982). A biotyping scheme for the subspecific discrimination of Escherichia coli. Journal of Medical Microbiology 15, 233242.

DoDD, C. E. R. \& Jones, D. (1982). A numerical taxonomic study of the genus Shigella. Journal of General Microbiology 128, 1933-1957.

EDWARDS, P. R. \& EWING, W. H. (1972). Identification of Enterobacteriaceae. Minneapolis: Burgess Publishing $C$.

Elek, S. D., Davies, J. R. \& Miles, R. (1973). Resistotyping of Shigella sonnei. Journal of Medical Microbiology 6, 329-345.

Elwell, L. P. \& Shipley, P. L. (1980). Plasmidmediated factors associated with virulence of bacteria to animals. Annual Review of Microbiology 34, 465-496.

Eveland, W. C., Oliver, W. J. \& Neel, J. V. (1971). Characteristics of Escherichia coli serotypes in the Yanomama, a primitive Indian tribe of South America. Infection and Immunity 4, 753-756.

GILLIES, R. R. (1978). Bacteriocin typing of Enterobacteriaceae. Methods in Microbiology 11, 79-86.

Goullet, P. (1973). An esterase zymogram of Escheri- 
chia coli. Journal of General Microbiology 77, 2735.

Goullet, P. (1980). Esterase electrophoretic pattern relatedness between Shigella species and Escherichia coli. Journal of General Microbiology 117, 493500 .

HARRIS, H., HopkinSON, D. A. \& EDWARDS, Y. H. (1977). Polymorphism and the subunit structure of enzymes: a contribution to the neutralist-selectionist controversy. Proceedings of the National Academy of Sciences of the United States of America 74, 698701.

Harshman, L. \& Riley, M. (1980). Conservation and variation of nucleotide sequences in Escherichia coli strains isolated from nature. Journal of Bacteriology 144, 560-568.

Helgason, S. \& Old, D. C. (1981). Comparison of four methods of differential typing of isolates of Shigella sonnei. Journal of Hygiene 87, 339-355.

HORI, H. \& OSAWA, S. (1978). Evolution of ribosomal proteins in Enterobacteriaceae. Journal of Bacterio$\operatorname{logy}$ 133, 1089-1095.

HORI, H. \& OSAWA, S. (1979). Evolutionary change in 5S RNA secondary structure and a phylogenetic tree of 54 5S RNA species. Proceedings of the National Academy of Sciences of the United States of America 76, 381-385.

JACQUARD, A. (1974). The Genetic Structure of Populations. New York: Springer-Verlag.

J Amieson, A. F., Bremner, D. A., Bergquist, P. L. \& LANE, H. E. D. (1979). Characterization of plasmids from antibiotic-resistant Shigella isolates by agarose gel electrophoresis. Journal of General Microbiology 113, 73-81.

JANN, K., JANN, B. \& SCHMIDT, G. (1981), SDS polyacrylamide gel electrophoresis and serological analysis of pili from Escherichia coli of different pathogenic origin. FEMS Microbiology Letters 11, 21-25.

Johnson, R., Colwell, R. R., Sakazaki, R. \& TAMURA, K. (1975). Numerical taxonomy study of the Enterobacteriaceae. International Journal of Systematic Bacteriology 25, 12-37.

KOCH, A. L. (1974). The pertinence of the periodic selection phenomenon to prokaryote evolution. Genetics 77, 127-142.

КосH, A. L. (1981). Evolution of antibiotic resistance gene function. Microbiological Reviews 45, 355378.

Kopecko, D. J., Washington, O. \& Formal, S. B. (1980). Genetic and physical evidence for plasmid control of Shigella sonnei form I cell surface antigen. Infection and Immunity 29, 207-214.

KRIEG, R. E. \& LockHART, W. R. (1966). Classification of enterobacteria based on overall similarity. Journal of Bacteriology 92, 1275-1280.

KUBITSCHEK, H. E. (1974). Operation of selection pressure on microbial populations. Symposia of the Society for General Microbiology 24, 105-130.

LEWoNTIN, R. C. (1974). The Genetic Basis of Evolutionary Change. New York: Columbia University Press.

Lewontin, R. C. \& HuBBy, J. L. (1966). A molecular approach to the study of genic heterozygosity in natural populations. II. Amount of variation and degree of heterozygosity in natural populations of Drosophila pseudoobscura. Genetics 54, 595-609.
LI, S.-L. \& Hoch, S. O. (1974). Amino-terminal sequence of the tryptophan synthetase $\alpha$ chain of Bacillus subtilis. Journal of Bacteriology 118, 187191.

MaYnard SMITH, J. \& HaIGH, J. (1974). The hitchhiking effect of a favourable gene. Genetical Research 23, 23-35.

Milch, H. (1978). Phage typing of Escherichia coli. Methods in Microbiology 11, 87-155.

MilkMaN, R. (1973). Electrophoretic variation in Escherichia coli from natural sources. Science 182, 1024-1026.

Milkman, R. (1975). Allozyme variation in E. coli of diverse natural origins. In Isozymes, IV. Genetics and Evolution, pp. 273-285. Edited by C. L. Markert. New York: Academic Press.

Milkman, R. \& CRawford, I. P. (1983). Clustered third-base substitutions among wild strains of Escherichia coli. Science (in the Press).

NeI, M. (1975). Molecular Population Genetics and Evolution. New York: Elsevier.

Nichols, B. P., Miozzari, G. F., Van Cleemput, M., BenNeTt, G. N. \& YANOFSKY, C. (1980). Nucleotide sequences of the $\operatorname{trp} \mathrm{G}$ region of Escherichia coli, Shigella dysenteriae, Salmonella typhimurium and Serratia marcescens. Journal of Molecular Biology 142, 503-517.

Nyman, K., Nakamura, K., Ohtsubo, H. \& Ohtsubo, E. (1981). Distribution of the insertion element ISI in gram-negative bacteria. Nature 289, 609-612.

Oнта, T. (1982). Linkage disequilibrium with the island model. Genetics 101, 139-155.

Old, D. C., Crichton, P. B., Maunder, A. J. \& WILSON, M. I. (1980). Discrimination of urinary strains of Escherichia coli by five typing methods. Journal of Medical Microbiology 13, 437-444.

Old, D. C., Helgason, S. \& Scott, A. C. (1981). Discrimination by multiple typing of isolates of Shigella sonnei in Dundee (1971-6). Journal of Hygiene 37, 357-368.

Ørskov, F., Ørskov, I., Evans, D. J., JR, SACK, R. B., SACK, D. A. \& WADSTrom, T. (1976). Special Escherichia coli serotypes among enterotoxigenic strains from diarrhoea in adults and children. Medical Microbiology and Immunology 162, 73-80.

ØRSKOV, I., ØRSKOV, F., JANN, B. \& JANN, K. (1977). Serology, chemistry, and genetics of $O$ and $K$ antigens of Escherichia coli. Bacteriological Reviews 41, 667-710.

Petrovskaya, V. G., \& Bondarenko, V. M. (1977). Recommended corrections to the classification of Shigella flexneri on a genetic basis. International Journal of Systematic Bacteriology 27, 171-175.

Petrovskaya, V. G. \& Khomenko, N. A. (1979). Proposals for improving the classification of members of the genus Shigella. International Journal of Systematic Bacteriology 29, 400-402.

Ramshaw, J. A. M., Coyne, J. A. \& Lewontin, R. C. (1979). The sensitivity of gel electrophoresis as an indicator of genetic variation. Genetics 93, 10191037.

Rowe, B., Gross, R. J. \& GuINEY, M. (1976). Antigenic relationships between Escherichia coli $\mathrm{O}$ antigens $\mathrm{O} 149$ to $\mathrm{O} 163$ and Shigella $\mathrm{O}$ antigens. International Journal of Systematic Bacteriology 26, 76-78. 
Sakazaki, R., Tamura, K., Johnson, R. \& Colwell, R. R. (1976). Taxonomy of some recently described species in the family Enterobacteriaceae. International Journal of Systematic Bacteriology 26, 158-179.

SANDERSON, K. E. (1976). Genetic relatedness in the family Enterobacteriaceae. Annual Review of Microbiology 30, 327-349.

Sansonetti, P. J., Kopecko, D. J. \& Formal, S. B. (1981). Shigella sonnei plasmids: evidence that a large plasmid is necessary for virulence. Infection and Immunity 34, 75-83.

Sansonetti, P. J., Kopecko, D. J. \& Formal, S. B. (1982). Involvement of a plasmid in the invasive ability of Shigella flexneri. Infection and Immunity 35, 852-860.

Selander, R. K. \& Levin, B. R. (1980). Genetic diversity and structure in Escherichia coli populations. Science 210, 545-547.

Selander, R. K. \& Whittam, T. S. (1983). Protein polymorphism and the genetic structure of populations. In Evolution of Genes and Proteins, pp. 89-114. Edited by M. Nei \& R. K. Koehn. Sunderland, Massachusetts: Sinauer Associates.

Selander, R. K., SMITH, M. H., YANG, S. Y., Johnson, W. E. \& GeNTRY, J. B. (1971). Biochemi- cal polymorphism and systematics in the genus Peromyscus. I. Variation in the old-field mouse (Peromyscus polionotus). Studies in Genetics VI (University of Texas Publication no. 7103), 4990.

Sneath, P. H. A. \& Sokal, R. R. (1973). Numerical Taxonomy. San Francisco: Freeman.

SzTURM-RUBINSTEN, S. (1964). Répartition géographique des biotypes et lysotypes de 743 souches de $S$ sonnei. Annales de l'Institut. Pasteur 106, 114122.

Thomson, G. (1977). The effect of a selected locus on linked neutral loci. Genetics 85, 753-788.

Whittam, T. S., Ochman, H. \& Selander, R. K. (1983). Multilocus genetic structure in natural populations of Escherichia coli. Proceedings of the National Academy of Sciences of the United States of America 80, 1751-1755.

Williams, P. H. \& Warner, P. J. (1980). Col V plasmid-mediated, colicin V-independent iron uptake system of invasive strains of Escherichia coli. Infection and Immunity 29, 411-416.

Wilson, A. C., Carlson, S. S. \& White, T. J. (1977). Biochemical evolution. Annual Review of Biochemistry 46, 573-639. 